\title{
JAN VAN BREEMEN, 1875-1961
}

The Nederlandse Vereniging van Rheumatologen regret to announce the death of their founder and honorary member, Jan van Breemen.

He died, after a short illness, at the age of 86 years, in his beloved city of Amsterdam, the freedom of which has been bestowed upon him many years ago.

In youth, he had desired to become a naval officer, but was refused owing to defective eyesight, a fact which, in years to come, he used to mention with an ironic smile, adding: " . . . and that's why, in the whole of my life, I have never had to wear glasses".

Nevertheless, he proved a true master mariner, exploring undiscovered provinces in rheumatology, letting his eyes sweep over vast horizons. A sailor at heart, he looked upon the entire world as his domain. Although a citizen of a small nation, he succeeded in uniting rheumatologists -in small numbers at the beginning-from all over the world: he was the founder and first secretary of the Ligue Internationale contre le Rhumatisme and of the Ligue Européenne contre le Rhumatisme. Even now there are few comparable international associations of medical specialists in existence.

Although no consummate linguist, he became a great orator through his love of truth, his originality in employing unorthodox manners of speech, and his personal charm.

Van Breemen was a loyal friend. From the walls of his study, which were hung with numerous portraits from many countries, the following motto greeted the visitor: "Of what can a man be proud if not of his friends."

Conversely, we all felt honoured by the friendship of this remarkable man, whose every single action testified to his rare unselfishness.

From DR. W. H. D. DE HAAs, Hon. Secretary,

Amsterdam.

W.S.C.C. WRITES: Dr. van Breemen, in the course of his life-long pioneering campaign to get the rheumatic diseases officially noticed by the academic medical "Establishments", gathered round him a band of enthusiasts from many countries. This group has much diminished in recent years, and of the original members of the International Committee on Rheumatism which he and Dr. Fortescue Fox founded jointly in 1927, only Dr. Jacques Forestier and myself survive. This committee they reorganized in the following year as the Ligue Internationale contre le Rhumatisme. One of the League's first activities was to stimulate the formation of national committees, whilst the international journal Acta Rheumatologica was started under the editorship of van Breemen, and continued to appear until the outbreak of war in 1939. It was he who was eventually able to convince the leaders of governmental and academic medicine in European countries that, the battle against the acute infective diseases being nearly won, the chronic diseases-more particularly those embraced by the term "rheumatic"-must now be seriously approached 
in the fields of both academic and sociological research. The Ligue Internationale held its sixth congress in England in 1938, and during a visit to Oxford Dr. van Breemen was presented with a fine Georgian bowl which had been subscribed for

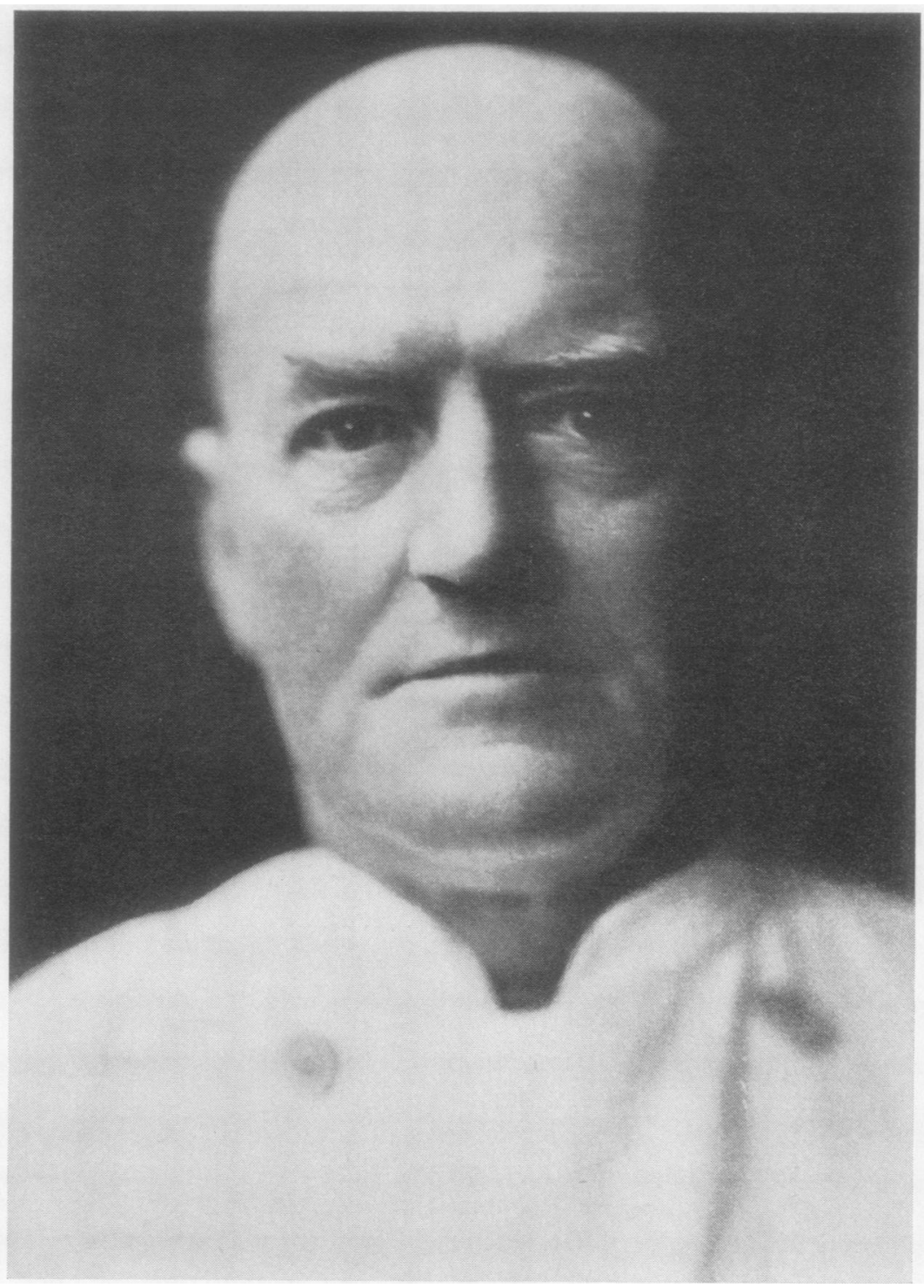

JAN VAN BREEMEN

by every member of the British branch. His delighted and fluent speech of thanks, which it was subsequently realized had been given in English, was long remembered by those present.

Van Breemen is the father of modern rheumatology and his memory will always be honoured in this country where, as in many others, he was well loved. 